\title{
Ozonlama Proses Şartlarının Elastansız Denim Kumaşların Yumuşaklık/Sertlik ve Mukavemet Özelliklerine Etkisinin İrdelenmesi
}

\section{Investigating the Effect of Ozonization Process Conditions on Softness/Stiffness and Strength Properties of Without Elastane Denim Fabrics}

\author{
Belkıs Zervent Ünal ${ }^{*}{ }^{\oplus}$, Ayşe Deniz Küçük ${ }^{2}$ (]) \\ ${ }^{1}$ Çukurova Üniversitesi Mühendislik Fakültesi Tekstil Mühendisliği, Adana, TÜRKiYE \\ 2 Çukurova Üniversitesi Mühendislik Fakültesi Tekstil Mühendisliği, Adana, TÜRKiYE \\ Sorumlu Yazar / Corresponding Author* : belzer@cu.edu.tr
}

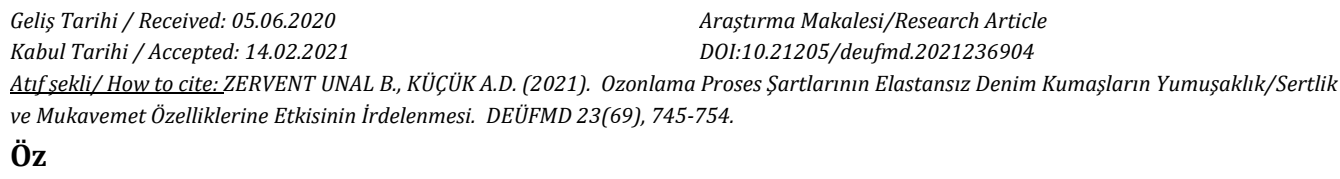

Çalışma kapsamında; güçlü oksidatif bir madde olan ozon gazı ile uygulanan efekt verme amaçlı ozonlama işleminin ve bu işlemin proses şartlarındaki değişimlerin elastansız denim kumaşların seçilmiș performans özellikleri üzerindeki etkisinin irdelenmesi amaçlanmıștır. Bu amaçla 2 tip denim kumaşa (çözgüsü halat ve slasher boyalı) 3 farklı ozonlama süresi (10-20-30 dakika) ve 4 farklı ozon oranında (\%40-\%60-\%80-\%100) ozonlama ișlemi uygulanmıștır. Ardından elde edilen kumaşlara kullanım yerine göre önemli olan kopma mukavemeti, yumuşaklık/sertlik ve spektrofotometrik renk analizi testleri uygulanmıştır. Elde edilen sonuçlar istatistiksel ve grafiksel olarak değerlendirilmiştir. Genel olarak; ozonlama süresi ve oranındaki artışın kopma mukavemeti değerlerini olumsuz etkilediği, sertliğe ise anlamlı bir etkisinin olmadığı tespit edilmiștir. Ayrıca halat ve slasher boyalı kumaşların ozonlama işlemi sonucu farklı davranışlar gösterdiği belirlenmiștir.

Anahtar Kelimeler: Denim kumaș, Ozonlama proses şartlarl, İndigo boyama, Kopma mukavemeti, Yumuşakllk

\section{Abstract}

In the scope of the study, it is aimed to examine the effect of ozonation process applied with ozone gas, which is a strong oxidative substance, and the effects of the changes in the process conditions on the selected performance properties of non-elastane denim fabrics. For this purpose, 3 different ozonation times (10-20-30 minutes) and 4 different ozone rates (40\%-60\%-80\%-100\%) were applied to 2 different denim fabrics (warp dyed with rope and slasher methods). Then, the tensile strength, softness/stiffness and spectrophotometric color analysis tests which are important properties according to the place of use were applied. The results obtained were evaluated statistically and graphically. Generally; it was determined that the increase in ozonation time and ozone rate affected the strength values negatively, but did not have a significant effect on stiffness. In addition, it was determined that rope and slasher dyed fabrics show different behaviors as a result of ozonation.

Keywords: Denim fabric, Ozonation process conditions, Indigo dyeing, Tensile strength, Softness 


\section{Giriș}

Tekstil ve konfeksiyon sanayisinin bilinen en eski kumaș tiplerinden biri olan denim kumaşların tarihi çok eski dönemlere dayanmakta ve güncelliğini yitirmeksizin her geçen gün önem kazanmaktadır. Hem ülkemizde hem de küresel pazarda ithalat ve ihracat değerleri incelendiğinde pazar payının her geçen gün arttığı gözlenmektedir.

İstanbul Tekstil ve Konfeksiyon İhracatçı Birlikler (ITKIB) tarafından 2019 yılında yayınlanan "Dünya Denim Kumaş Dış Ticaret Raporu"'na göre Türkiye'nin 2019 yllı OcakAğustos dönemi denim kumaş ihracatında $\% 16,9$ oranında gerileyerek 194 milyon dolar, denim kumaş ithalatında ise \%23,6 oranında gerileyerek 155 milyon dolar değerinde gerçekleşmiştir. Aynı rapora göre 2019 yılı Ocak-Ağustos dönemi Türkiye'nin en fazla denim kumaș ihracatı gerçekleștirdiği ülke Tunus, ithalat da ise Pakistan olduğu görülmektedir [1].

Denim kumaşlara çeşitli yöntemlerle müșteri isteklerine ve moda akımlarına göre yıpranmış, yıllanmış ve giyilmiş efektler kazandırmak için ağartma ve yıkama işlemleri yapılmaktadır. Günümüzde özel yıkama ișlemlerine tabi tutularak farklı renk, tuşe ve yüzey elde etmek mümkündür.

Tekstil sanayisi içerisinde özellikle terbiye sektöründe atık su, boyarmadde, kimyasal ve tehlikeli maddeler gibi çevreye zararlı bileșenler oldukça fazla oranda bulunmaktadır. Bu nedenlerle hem doğal çevreye hem de insan sağlığına zarar vermeyen, sürdürülebilir üretim yöntemleri arayışları hız kazanmaktadır. Bu bağlamda ozon gazının kullanımı yaygınlașmaya başlamıștır.

Denim sektöründe toksik madde içermeyen, doğaya serbest halde yayıldı̆̆ında oksijene dönüșerek zararsız bir yapıya kendiliğinden dönen, çamaşır yıkama sistemlerinde sadece bir yıkama-bir durulama ișlemi yapılarak, sıcak suya ihtiyaç duyulmadan yıkama gerçekleştirebilen ve bu sayede \%50'ye varan oranda deterjan, elektrik ve su tasarrufu sağlayan ozon gazı kullanımı ile eskitme/ağartma efektleri verilebilmektedir [2].

Prabaharan ve arkadaşları, 2000 yılında yapmış oldukları çalışmada pamuklu kumaşların ağartılmalarında ozon gazının etkinliğini irdelemişlerdir. Pamuklu kumaşların ozon ile ağartma işlemiyle kısa sürede kabul edilebilir beyazlık değerlerine ulaşıldığı görülmüștür. Ayrıca yüksek ozon konsantrasyonlarında ozon ile ișlem görmüș kumașların boya alımlarında düşüş meydana gelmiştir. Bunlara ek olarak pamuklu mamullerde en iyi beyazlık derecesi ve en az mukavemet kaybı için kısa uygulama süresi ve yüksek ozon konsantrasyonunun gerektiği tespit edilmiştir [3].

Micheal ve El-Zaher, 2003 yılında yapmış oldukları çalıșmada temizlenmemiș yün kumaș kullanarak UV/ozon uygulamasının yün kumașın geçirgenlik, ıslanabilirlik ve sarılık indeksini arttırdığı sonucuna ulaşmışlardır. Ayrıca bu etkilerin uygulama süresinin artmasıyla daha da belirginleștiğini belirtmişlerdir. Bunlara ek olarak ışık haslıklarının arttığı ve boyanabilirlik özelliğinin ilk uygulamalardan itibaren sürekli bir yükseliş halinde olduğu sonucuna ulaşmışlardır [4].

Cardis ve arkadaşları, 2007 yılında hazır giyim yıkama proseslerinde ozon teknolojisinin kullanımı üzerine bir çalıșma yapmıșlardır. Araştırmalarında, ozon ile yıkama işleminin enerji ve su tüketiminde tasarruf sağladığ vurgulanmıştır. Ayrıca yıkama sayılarının azalışı ve deterjan kullanımındaki düşüş ozonun bu prosese diğer katkıları olarak görülmektedir [5].

Poznyak ve arkadașları, 2007 yılında yapmıș oldukları çalışmada tekstil sektöründe en çok kullanılan ve karışık kimyasal yapıya sahip üç boyarmaddenin ozonlama işlemi ile sulu çözeltiden uzaklaştırılması üzerine çalıșmışlardır. Kullanılan tüm boyarmaddeler için, 1,5-2 dakikalık ozonlama süresinin rengin tamamen kaybolması için yeterli olduğu görülmüştür [6].

Gülümser ve arkadașları, 2009 yılında ozonun yün liflerinin ağartılmasında kullanılabilirliğini araștırdıkları bir deneysel çalıșma yürütmüşlerdir. Farklı \%AF nem değerlerine sahip numunelere sabit sıcaklıkta uygulanan 5 dakikalık işlem neticesinde en iyi beyazlık derecesine \%20-30 nem değeri aralığında ulaşıldığı görülmüștür. Farklı sürelerde (1-5-1530-60 dakika) ozonlama ișlemine tabi tutulmuş kumaşlarda ise işlem süresi arttıkça beyazlık derecesinin de arttı̆̆ı sonucuna ulașılmıştır. 
Ancak 1 dakikalık ozonlama ișleminde istenilen beyazlık derecesi elde edilememiştir [7].

Rice ve arkadașları (2009) ozon ile yıkama işlemleri üzerinde araștırmalar yapmıșlardır. Çalışmalarına göre ozonun, geleneksel yıkama sistemlerine göre daha az kimyasal madde ve deterjan kullanılmasından dolayı kimyasal madde tasarrufu sağladığı vurgulanmıştır. Ayrıca ozon ile yıkama sisteminde soğuk su (oda sıcaklığı ve musluk suyu) kullanımından dolayı enerji tasarrufu sağlandığını belirtmişlerdir. Aynı zamanda ozon yıkama sisteminde düșük sıcaklığa ihtiyaç duyulmasının, çalkalama süresindeki ve kullanılan kimyasal miktarındaki azalmanın kumașın ömrünü uzattığı yönünde gelișme sağlandığını vurgulamışlardır [8].

Öztürk ve Eren, 2010 yılında ozonun genel özelliklerinin ve tekstil terbiyesinde ozonun kullanım olanaklarının derlendiği bir çalışma yapmıșlardır. Genel olarak pamuğun, jütün, ipeğin ve yünün ağartılmasında, yün lifinin keçeleşmezlik işlemlerinde, nylon, polilaktikasit (PLA) ve poliester liflerinin terbiyesinde, denim yıkamada ve boyama atık sularının renk giderimi ișlemlerinde ozon kullanımının söz konusu olduğu belirtilmiștir [9].

Sancar Beșen, 2012 yılında yapmıș olduğu tezin denim uygulamaları kısmında indigo boyalı pamuk iplikleri üzerine ağartma efekti uygulamak amaciyla ozon gazının kullanılabilirliğini irdelemiştir. Bu amaçla bazı ozonlama parametrelerinin ve ipliklerin boyama reçetelerinin ağartma efekti üzerindeki etkisi araștırılmıștır. Sonuç olarak ozonlama süresinin, ozon konsantrasyonunun ve ipliklerin boyama reçetelerinin denim kumașların efektlendirilmesi üzerinde etkili olduğu sonucuna varılmıștır. Zemini kükürt boyarmaddeler ile boyanmıș ipliklerin renkleri, zemini boyasız sadece indigo boyarmaddeli ipliklere göre daha fazla açlmakta, ozonlama süresi ve ozon konsantrasyonu yükseldikçe numunelerin ağartma efektlerinin arttığı ve mukavemet değerlerinin azaldığı sonucuna varılmıştır [10].

Perinçek ve arkadaşları, 2013 yılında keten kumaşların ozon ile ağartılması üzerine bir makale yayınlamışlardır. Ham keten kumaşların ozon ile ağartılmasında farklı ișlem süreleri (510-15 dakika) kullanılmış ve sonrasında kumaşlar çeșitli şartlarda hidrojen peroksit ile muamele edilmiștir. Süre ve kimyasal madde kullanımı açısından tasarruf sağlamak için peroksit ile ağartmadan önce 15 dakika ozonlama ișleminin yapılması önerilmiștir [11].

İyizaman, 2014 yılında yapmış olduğu tez çalışmasında, dispers boyama atık suyunun ozonlama işlemi uygulanarak optimum koşullarda renksizleștirilmesi, söz konusu atık su ile tekrar boyama yapılması ve boyama sonucunda elde edilen kumaşın fiziksel özelliklerinin değerlendirilmesi amaçlanmıștır. Çalışma kapsamında; ozonun KOİ değerleri üzerinde azaltıcı etkisi olduğu sonucuna varılmıștır. Ayrıca ozonlanarak geri kazanılan dispers atı suları kullanılarak yapılan boyamalardan elde edilen kumașların mukavemet ve haslık test değerlerinde olumsuz bir değişim görülmemiştir [12].

Benli ve Bahtiyari, 2016 yılında yükseltgen özelliği olan ozon ve hidrojen peroksiti oda sıcaklığında birleștirerek ağartma işlemlerinde ve seçilmiş doğal boyalarla boyamada kullanılabilirliğini irdelemișlerdir. Çalıșma kapsamında $40 \mathrm{ml} / \mathrm{l} \mathrm{H}_{2} \mathrm{O}_{2}$ içeren, $\mathrm{pH}^{\prime} 17$ olan ağartma banyosunda \%50 flotte oranında emdirilen, ardından kapalı sistem içerisinde 60 dakika ozonlama işlemine maruz bırakılan numune kumaşlarda yeterli terbiye efektlerinin sağlanabildiği sonucuna varılmıştır [13].

Soydaș, 2016 yılında ozonlama ișleminin havlu kumaşların ağartılması ve hidrofilleştirilmesi üzerine etkisini irdelemiștir. Sonuç olarak çalışmadaki bütün gramajlarda ozonlama ișlem süresi 45 dakika olduğunda en iyi hidrofilite elde edilmiștir. Farklı ozon gaz akıșı parametresinde ise $1000 \mathrm{ml} / \mathrm{dk}^{\prime} \mathrm{llk}$ ozon gazı akışında kumaşların gösterdiği hidrofilite derecesinin daha fazla olduğu sonucuna varılmıştır [14].

Kır, 2019 yılında yapmıs oluğu tez çalıșmasında yumuşatıcı, su iticilik ve buruşmazlık bitim işlemi uygulanmış denim kumaşların, uygulama sonrası üzerine aktarılan apre kimyasalının ozon ile efektlendirme verimine olan tesiri ve efektlendirme ișlemi sonrasında tușe ve kumaș performans özellikleri üzerindeki etkileri incelemiştir. Yumuşatıcı ve su iticilik bitim işlemi sonucunda, dairesel eğilme dayanımı, yırtılma mukavemeti ve eğilme dayanımı test sonuçlarının pozitif yönde, buruşmazlı̆̆ın ise negatif yönde etkilendiği görülmüștür [15]. 
Calıșmada kapsamında, ozonlama ișleminin ve proses şartlarının elastansız denim kumaşların seçilmiş performans özellikleri üzerine etkisinin irdelenebilmesi amaciyla numune kumaşlara kopma mukavemeti ve sertlik testleri uygulanmış, bunun yanısıra spektrofotometre yardımıyla renk değișimi analiz edilmiștir. Elde edilen sonuçlar grafiksel ve istatistiksel olarak değerlendirilmiștir.

\section{Materyal ve Metot}

\subsection{Materyal}

Çalışma kapsamında, ozonlama işlemi ve değișen proses şartlarının seçilmiş elastansız denim kumaşlarda kopma mukavemeti ve sertlik değerleri üzerindeki etkisinin belirlenmesi amaçlanmıştır.Ayrıca numunelerin farklı ozonlama prosesleri sonrası renginde meydana gelen değişimlerde irdelenmiştir. $\mathrm{Bu}$ kapsamda, belirli gramajda çözgü ipliği indigo boyalı, atkı ipliği boyanmamıș (ham) ve $3 / 1 \mathrm{Z}$ dimi denim kumaşlar kullanılmıştır. Farklı indigo boyama tekniklerinin ozonlama performansına etkisini belirlemek amaciyla çözgüsü halat boyalı ve slasher boyalı olmak üzere 2 tip denim kumaş üretimi gerçekleștirilmiştir. "RH1" ve "RS1" olarak kodlanan numunelerin dokuma kumas konstrüksiyon özellikleri Tablo 1'de gösterilmiştir.

Tablo 1. Numune kumaşların konstrüksiyon özellikleri.

\begin{tabular}{|l|l|l|}
\hline Numune kodu & RH1 & RS1 \\
\hline Hammaddesi & $\% 100$ pamuk & $\% 100$ pamuk \\
\hline $\begin{array}{l}\text { Cözgü boyama } \\
\text { tekniği }\end{array}$ & $\begin{array}{l}\text { Halat } \\
\text { boyama }\end{array}$ & $\begin{array}{l}\text { Slasher } \\
\text { boyama }\end{array}$ \\
\hline Gramaj (g/m²) & 431,74 & 391,18 \\
\hline Çözgü sıklı̆̆ı (tel/cm) & 28 & 28 \\
\hline Atkı sıklığı (tel/cm) & 18 & 18 \\
\hline Cözgü numarası (Ne) & $7,1 / 1$ & $8,1 / 1$ \\
\hline Atkı numarası (Ne) & $8,9 / 1$ & $8,7 / 1$ \\
\hline Örgü tipi & $3 / 1 \mathrm{Z} \mathrm{Dimi}$ & $3 / 1 \mathrm{Z} \mathrm{Dimi}$ \\
\hline
\end{tabular}

\subsection{Metot}

\subsubsection{Ozonlama işlemi}

Dokuması tamamlanan numune kumaşlara ozon ile ağartma işlemleri öncesinde en az yıkama efekti vermesi nedeniyle "TolkarSmartex Miracle ${ }^{\circledR ”}$ rins yıkama makinesinde işlem uygulanmıştır. Yıkama işlemi sonrasında ise boşaltma, sıkma ve kurutma ișlemi gerçekleştirilmiştir. Rins yıkama sonrası ozon ile ağartma işlemleri için Corona Dischange esasına dayanan Jeanologia marka "X-ARC 400" model ozon jeneratörü kullanılmıştır. Coronadischarge esaslı ozon jeneratörünün çalışma prensibi; sabit elektrik akımı vererek elektronları hızlandırmak suretiyle kinetik enerji kazandırarak, oksijen molekülündeki oksijen-oksijen çift bağını parçalamak esasına dayanmaktadır. Bu işlem sonunda açığa çıkan iki oksijen atomu, ozonu oluşturmak üzere diğer oksijen molekülü ile reaksiyona girmektedir. Ozon jeneratörü vasıtasıyla sanayi tipi yıkama makinesine beslemesi yapilan ozon gazı ile ağartma işlemi yapılmaktadır. Denim mamullerin ozon ile ağartılması numune üzerindeki indigonun oksidasyonu șeklinde tanımlanabilmektedir. İsatin, antranilik asit ve bu iki ürünün karışımları olan yan ürünler indigonun oksidasyonu sonucunda meydana gelmektedir. $\mathrm{Bu}$ yan ürünler nedeniyle denim mamullerin yüzeyi sarı renge dönmekte ve ișlem sonrası yapılan durulama ile bu yan ürünlerin uzaklaștırılması sonucunda mamul üzerindeki sarılık giderilmektedir. Böylece numunelere ağartılmış denim efekti verilmektedir [16].

Çalıșma kapsamında, ozonlama işleminin denim kumaș özelliklerine etkisinin irdelenebilmesi için uygulanan farklı ozonlama proses şartları (deney planı) Tablo 2'de verilmiştir. Bu amaçla 2 farklı denim kumaşa 3 farklı ozonlama süresi (10-20-30 dakika) ve 4 farklı ozon oranlarında (\%40-\%60-\%80-\%100) işlem uygulanmıştır. Deneysel çalışmada kullanılan ozon oranlarını elde etmek için kullanılan ozon miktarları sırasıyla \%40 için 166,46 g/saat, \%60 için $246,19 \mathrm{~g} /$ saat, \%80 için 324,69 g/saat ve \%100 için 411,0 g/saat șekildedir. Bu kapsamda 2 tip denim kumaşa 7 farklı proses uygulanmıș ve böylelikle 14 farklı numune kumaş elde edilmiştir. Yapılan her işlem bir kez tekrarlanmıștır. 
Tablo 2. Numune kumas özellikleri ve ozonlama proses sartları.

\begin{tabular}{|c|c|c|c|c|}
\hline $\begin{array}{l}\text { Numune } \\
\text { Kumaş } \\
\text { Kodu }\end{array}$ & $\begin{array}{l}\text { İndigo } \\
\text { Boyama } \\
\text { Tekniği }\end{array}$ & $\begin{array}{l}\text { Ön } \\
\text { İşlem }\end{array}$ & $\begin{array}{l}\text { Ozon } \\
\text { Oranı }\end{array}$ & $\begin{array}{l}\text { Ozon } \\
\text { Süresi }\end{array}$ \\
\hline RH1 & $\begin{array}{l}\text { Halat } \\
\text { boyama }\end{array}$ & & & \\
\hline RS1 & $\begin{array}{l}\text { Slasher } \\
\text { boyama }\end{array}$ & & & \\
\hline RH2 & \multirow{6}{*}{$\begin{array}{l}\text { Halat } \\
\text { boyama }\end{array}$} & \multirow{6}{*}{$\begin{array}{l}\text { Rins } \\
\text { yılkama }\end{array}$} & \multirow{3}{*}{$\% 100$} & 10 dakika \\
\hline RH3 & & & & 20 dakika \\
\hline RH4 & & & & 30 dakika \\
\hline RH5 & & & $\% 40$ & \multirow{3}{*}{20 dakika } \\
\hline RH6 & & & $\% 60$ & \\
\hline RH7 & & & $\% 80$ & \\
\hline RS2 & \multirow{6}{*}{$\begin{array}{l}\text { Slasher } \\
\text { boyama }\end{array}$} & \multirow{6}{*}{$\begin{array}{l}\text { Rins } \\
\text { yıkama }\end{array}$} & & 10 dakika \\
\hline RS3 & & & $\% 100$ & 20 dakika \\
\hline RS4 & & & & 30 dakika \\
\hline RS5 & & & $\% 40$ & \multirow{3}{*}{20 dakika } \\
\hline RS6 & & & $\% 60$ & \\
\hline RS7 & & & $\% 80$ & \\
\hline
\end{tabular}

\subsubsection{Kopma mukavemeti tayini}

TS EN ISO 13934-1:2013-"Tekstil-Kumașların Gerilme Özellikleri-Bölüm 1: En Büyük Kuvvetin ve En Büyük Kuvvet Altında Boyca Uzamanın Tayini-Şerit Metodu" standardına göre numunelerin kopma mukavemeti tayini testleri Titan Universal mukavemet test cihazında gerçekleștirilmiştir. Çalışmada kullanılan tüm numuneler için 5 çözgü yönünde, 5 atkı yönünde numune test edilerek kopma mukavemeti değerleri "Newton" cinsinden ölçülmüştür [17].

\subsubsection{Sertlik derecesi tayini}

Numune kumașların sertlik değerlerini belirlemek için Dijital Pnömatik Stiffnes Tester cihazı ve ASTM (American Society for Testing and Materials) D 4032-08:2016 Standard Test
Method for Stiffness of Fabric by the Circular Bend Procedure (Dairesel Eğme Prosedürü ile Kumaş Sertliği için Standart Test Metodu) esas alınmış, her numune için 3 ölçüm yapılmıştır [18].

\subsubsection{Spektrofotometrik renk analizi}

Ozon ile ağartılmış denim kumaşlara Minolta CM 3600 D Spektrofotometre Renk Ölçüm Cihazı ve RealColor1.3 ${ }^{\circledR}$ yazılımı kullanılarak renk analizi yapılmıștır.

\section{Bulgular \\ 3.1. Kopma mukavemet test sonuçları}

Titan Universal test cihazı ile yapılan mukavemet testi ölçüm sonuçları Tablo 3'de verilmiștir. Tablodan görüldüğü gibi numunelerin çözgü yönündeki kopma mukavemeti değerleri minimum 1080,94 N, atkı yönündeki kopma mukavemeti değerleri ise minimum 602,32 $\mathrm{N}$ olarak tespit edilmiștir. TS 2791'a göre denim kumaşların kopma mukavemetinde gramajına bağlı olarak değișen alt limit değerleri bulunmaktadır [19]. Bu standart değerler göz önüne alındığında çözgü ve atkl yönündeki tüm numunelerin kopma mukavemetlerinin söz konusu alt limitlerin üstünde olduğu görülmektedir.

Kopma mukavemeti sonuçları, ozonlama işlem süresi (Şekil 1, Şekil 2) ve ozon oranına (Şekil 3, Şekil 4) göre irdelenmiş ve grafikler bu parametreler için ayrı ayrı düzenlenerek yorumlanmıştır.

Ayrıca çalışma kapsamında üretilen numunelerin seçilmiș performans özelliklerinin test sonuçları SPSS istatiksel analiz programı yardımıyla istatistiksel olarak da irdelenmiștir. Genel olarak t-testi sonucu elde edilen "sig." değerlerinin 0,05 'den küçük olması durumunda "ele alınan iki değișkenin ortalamaları arasında istatistiksel olarak anlamlı bir fark vardır" değerlendirmesi yapılırken, "sig." değerlerinin 0,05'den büyük olması ise "istatistiksel olarak anlamlı bir fark yoktur" şeklinde yorumlanmaktadır. Varyans analizi sonuçlarında ise "sig." değerlerinin 0,01'den küçük olması "ortalamalar arasında istatistiksel olarak anlamlı bir fark vardır" şeklinde değerlendirilmektedir. 
DEÜ FMD 23(69), 745-754, 2021

Tablo 3. Numunelerin kopma mukavemet değerleri.

\begin{tabular}{|l|l|l|}
\hline \multirow{2}{*}{$\begin{array}{l}\text { Numune } \\
\text { Kodları }\end{array}$} & \multicolumn{2}{|l|}{ Ortalama Kopma Mukavemeti (N) } \\
\cline { 2 - 3 } Çözgü & Atkı \\
\hline RH1 & 1783,89 & 883,50 \\
\hline RH2 & 1600,94 & 829,67 \\
\hline RH3 & 1448,56 & 622,06 \\
\hline RH4 & 1263,87 & 602,32 \\
\hline RH5 & 1538,55 & 745,12 \\
\hline RH6 & 1552,27 & 667,70 \\
\hline RH7 & 1518,16 & 647,36 \\
\hline RS1 & 1539,82 & 913,97 \\
\hline RS2 & 1318,28 & 822,75 \\
\hline RS3 & 1141,71 & 657,13 \\
\hline RS4 & 1080,94 & 564,33 \\
\hline RS5 & 1392,12 & 802,25 \\
\hline RS6 & 1200,55 & 652,73 \\
\hline RS7 & 1121,04 & 647,53 \\
\hline
\end{tabular}

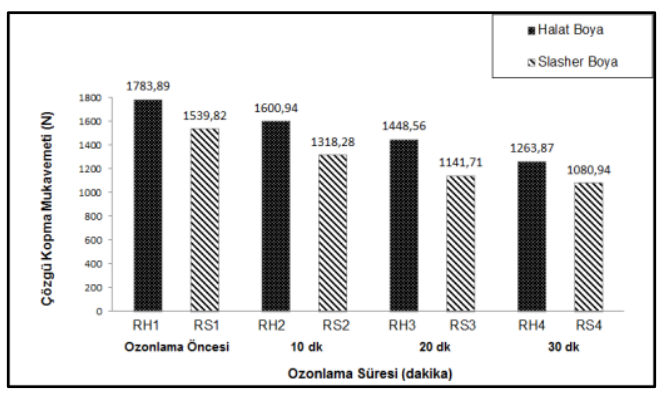

Şekil 1. Farklı sürelerde ozon ile ağartılmış numunelerin çözgü kopma mukavemet değerleri

Farklı sürelerde ozon ile ağartılmıș elastansız (rijit) numunelerin çözgü kopma mukavemet değerlerinin verildiği Şekil 1'e göre hem slasher hem halat boyalı denim kumaşlarda ozonlama ișlemi mukavemet kaybına yol açmıștır. $\mathrm{Bu}$ durumun hem ozon ile yapılan muamele hem de ozonlama öncesi uygulanan ön işlemden dolayı oluşan kumaş deformasyonundan kaynaklanabildiği düşünülmektedir. Ayrıca her iki kumaș tipinde de ozonlama süresi artıkça mukavemet değerlerinin azaldığı net bir şekilde görülmektedir. İndigo boyama tipi ile çözgü kopma mukavemeti arasında istatistiksel olarak da anlamlı bir ilişki olduğu görülmüștür (sig. 0,001).

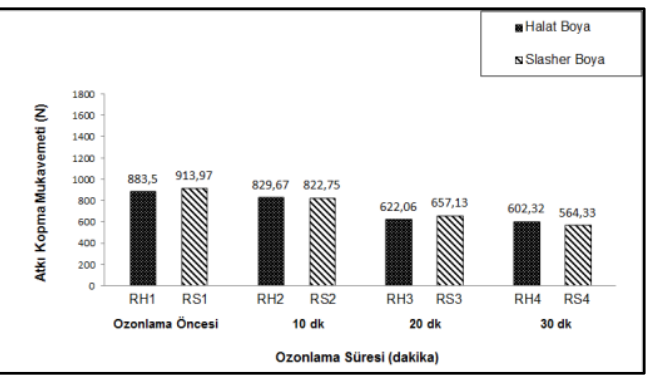

Şekil 2. Farklı sürelerde ozon ile ağartılmıș numunelerin atkı kopma mukavemet değerleri

Farklı sürelerde ozon ile ağartılmış numunelerin atkı kopma mukavemet değerlerinin gösterildiği Şekil 2'ye göre hem halat boyalı hem de slasher boyalı numunelerin birbirine yakın değerlerde oldukları görülmektedir. İstatistiksel olarak da boyama tipi ile atkı kopma mukavemeti arasında anlamlı bir ilişki tespit edilememiştir (sig. 0,955). Genel olarak ozon ile ağartma işlem süresi arttıkça numunelerde mukavemet kaybı yaşandığı gözlenmektedir.

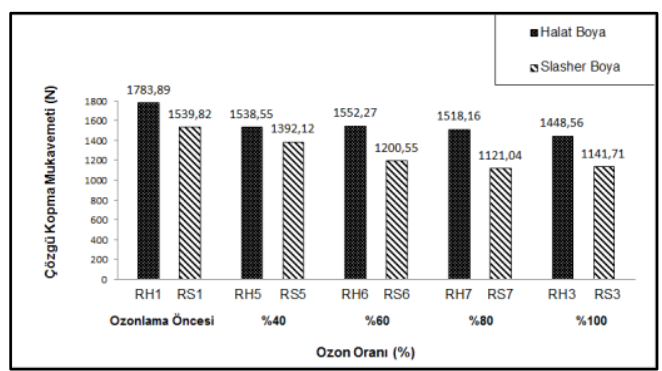

Şekil 3. Farklı ozon oranlarıyla ağartılmış numunelerin çözgü kopma mukavemet değerleri

Şekil 3 incelendiğinde hem halat boyalı hem de slasher boyalı numune gruplarının ozon oranı arttıkça çözgü kopma mukavemet değerlerinin düștüğü tespit edilmiștir. 
DEÜ FMD 23(69), 745-754, 2021

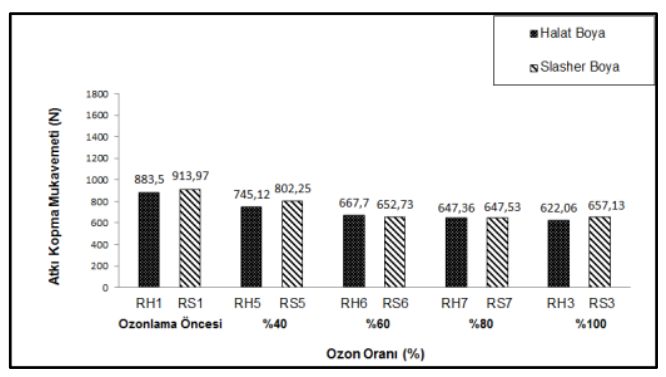

Șekil 4. Farklı ozon oranlarıyla ağartılmıș numunelerin atkı kopma mukavemet değerleri

Farklı ozon oranlarıyla ağartılmış elastansız numunelerin atkl kopma mukavemet değerlerinin gösterildiği Şekil 4'e göre hem halat boyalı hem de slasher boyalı numunelerin ozonlama işleminden olumsuz etkilendiği belirlenmiștir. Ayrıca ozon oranının \%40'dan $\% 60$ 'a çıkarılmasının elastansız numunelerin atkı kopma mukavemet değerlerini düşürdüğü tespit edilmiştir. Ancak bu değerden sonra mukavemet kaybının ihmal edilebilir düzeyde olduğu görülmektedir. Ozon oranı değișkeni ile çözgü (sig. 0,841) ve atkı (sig. 0,501) kopma mukavemet değerleri arasında istatistiksel olarak anlamlı bir etki tespit edilememiștir.

\subsection{Sertlik derecesi tayini test sonuçları}

Stiffness Tester Cihazı ile yapılan sertlik derecesi tayini testi sonucu elde edilen değerler "kgf" cinsinden Tablo 4'de verilmiştir. Yapılan ölçümlerde bu değerlerin düșmesi, numunelerin sertliğinin azaldığı başka bir ifadeyle yumuşaklık özelliğinin iyileștiği, dökümlülüğünün arttığı anlamına gelmektedir.

Deneysel çalışmada elde edilen test sonuçları grafiksel olarak değerlendirilirken sertlik değerleri test sonuçları ozonlama süresi (Şekil 5) ve ozon oranına (Șekil 6) göre ayrı ayrı irdelenmiştir.
Tablo 4. Numunelerin sertlik değerleri.

\begin{tabular}{|l|l|}
\hline Numune Kodları & $\begin{array}{l}\text { Ortalama Sertlik Değerleri } \\
\text { (kgf) }\end{array}$ \\
\hline RH1 & 1,818 \\
\hline RH2 & 0,594 \\
\hline RH3 & 0,601 \\
\hline RH4 & 0,606 \\
\hline RH5 & 0,617 \\
\hline RH6 & 0,601 \\
\hline RH7 & 0,671 \\
\hline RS1 & 1,171 \\
\hline RS2 & 0,455 \\
\hline RS3 & 0,488 \\
\hline RS4 & 0,443 \\
\hline RS5 & 0,411 \\
\hline RS6 & 0,467 \\
\hline RS7 & 0,461 \\
\hline
\end{tabular}

Şekil 5'e göre ozonlama işlemi uygulanan numunelerin (hem halat boyall, hem de slasher boyalı) ozonlama işlemi öncesine göre oldukça düşük sertlik değerlerine sahip olduğu, başka bir ifadeyle kumaşların ozonlama sonrası daha yumuşak olduğu görülmektedir. Bu durumun ozon ile ağartma proseslerinde uygulanan aşındırma efektinden ve ön işlem olarak uygulanan yıkama işlemlerinden kaynaklandığı düșünülmektedir. Ayrıca ozonlama ișlem süresindeki artışın (10-20-30 dakika) sertlik değerleri üzerinde anlamlı bir değişime neden olmadığı görülmektedir. Elde edilen istatiksel sonuçlara göre de ozon süresinin sertlik değerleri üzerinde istatistiksel olarak anlamlı bir etkisinin olmadığı tespit edilmiștir (sig. 0,978). 
DEÜ FMD 23(69), 745-754, 2021

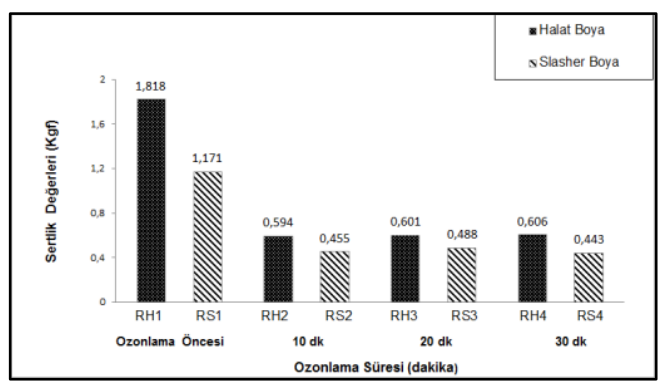

Şekil 5. Farklı sürelerde ozon ile ağartılmış numunelerin sertlik değerleri

Farklı ozon oranlarıyla ağartılmış numunelerin sertlik değerlerinin verildiği Şekil 6'ya göre ozonlama süresi parametresinde olduğu gibi ozon oranı parametresinde de (\%40-\%60-\%80$\% 100$ ) numuneler kendi arasinda değerlendirildiğinde, sertlik değeri üzerinde anlamlı bir etkisi olmadığı grafiklerden net bir şekilde görülmektedir. Ozon oranı değișkeni ile sertlik değeri arasında istatistiksel olarak da anlamlı bir etki tespit edilememiștir (sig. 0,956).

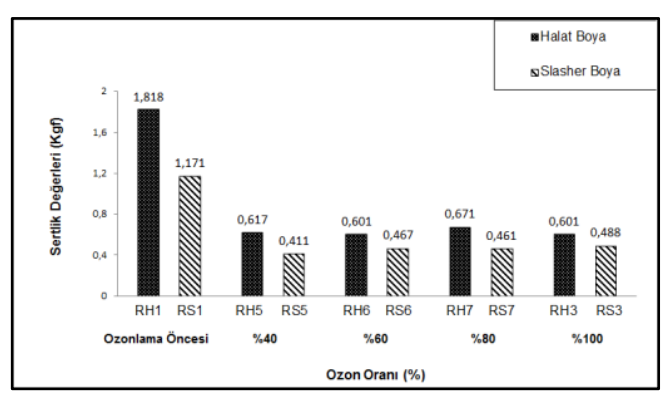

Şekil 6. Farklı ozon oranlarıyla ağartılmış numunelerin sertlik değerleri

\subsection{Spektrofotometrik renk analizi test sonuçları}

Minolta CM 3600 D Spektrofotometre renk ölçüm cihazı kullanılarak yapılan renk analizi sonuçları Tablo 5'de verilmektedir.

Tablo 5 irdelendiğinde halat boyalı numune gruplarının slasher boyalı numune gruplarına göre $\Delta \mathrm{E}$ yani renk farklılıklarının biraz daha fazla olduğu görülmektedir. Ayrıca halat boyalı numuneler ozonlama süresi açısından irdelendiğinde en fazla renk farkının 10 dakika (RH2) ve 30 dakika (RH4) işleme tabi tutulmuş kumaşlar arasında olduğu görülmektedir. Ozon oranı açısından ise RH5 (\%40) ve RH3 (\%100) kodlu numuneler arasındaki renk farkının en yüksek olduğu gözlenmektedir.
Tablo 5. Numuneler arası $\Delta \mathrm{E}$ değerleri.

\begin{tabular}{|l|l|l|l|}
\hline $\begin{array}{l}\text { Referans } \\
\text { Kumune }\end{array}$ & $\begin{array}{c}\text { Karşlaştırılan } \\
\text { Numune } \\
\text { Kodları }\end{array}$ & $\begin{array}{l}\text { Kod } \\
\text { Açıllamaları }\end{array}$ & \multicolumn{1}{|c|}{} \\
\hline RH2 & RH3 & $10^{\prime}-20^{\prime}$ & 23,54 \\
\hline RH2 & RH4 & $10^{\prime}-30^{\prime}$ & 32,49 \\
\hline RH3 & RH4 & $20^{\prime}-30^{\prime}$ & 9,64 \\
\hline RH5 & RH6 & $\% 40-\% 60$ & 14,4 \\
\hline RH5 & RH7 & $\% 40-\% 80$ & 19,01 \\
\hline RH5 & RH3 & $\% 40-\% 100$ & 26,3 \\
\hline RH6 & RH7 & $\% 60-\% 80$ & 4.73 \\
\hline RH6 & RH3 & $\% 60-\% 100$ & 11,99 \\
\hline RH7 & RH3 & $\% 80-\% 100$ & 7,51 \\
\hline RS2 & RS3 & $10^{\prime}-20^{\prime}$ & 21,12 \\
\hline RS2 & RS4 & $10^{\prime}-300^{\prime}$ & 30,67 \\
\hline RS3 & RS4 & $20^{\prime}-30^{\prime}$ & 10,24 \\
\hline RS5 & RS6 & $\% 40-\% 60$ & 12,41 \\
\hline RS5 & RS7 & $\% 40-\% 80$ & 18.84 \\
\hline RS5 & RS3 & $\% 40-\% 100$ & 23,04 \\
\hline RS6 & RS7 & $\% 60-\% 80$ & 6,47 \\
\hline RS6 & RS3 & $\% 60-\% 100$ & 10,71 \\
\hline RS7 & RS3 & $\% 80-\% 100$ & 4,5 \\
\hline
\end{tabular}

Çözgü ipliği slasher boyalı numunelerde de yine süre parametresi açısından 10 dakika ve 30 dakika arasında, ozon oranı açısından ise $\% 40$ ve \%100 ozonlanmıș kumaşlarda renk farkının daha fazla olduğu görülmektedir. Bunun yanı sıra 10-20 dakikalık numuneler arasındaki renk farkının 20-30 dakika ișlem görmüș numuneler arasındaki renk farkından oldukça yüksek olduğu dolayısıyla ozonlama süresi arttıkça meydana gelen renk açılmasının azaldığı ve bu durumun hem halat hem slasher boyalı kumaşlar için de geçerli olduğu görülmüştür.

\section{Tartışma ve Sonuçlar}

Çalışma kapsamında; sürdürülebilir bir uygulama olan ozon gazının seçilmiş denim kumaşların performans özellikleri üzerindeki 
etkisini ortaya koymak amaçlanmıștır. $\mathrm{Bu}$ kapsamda yapılan deneysel çalıșma neticesinde elde edilen sonuçlar grafiksel olarak değerlendirilmiş ve edilen sonuçlardan seçilmiş olanlar aşağıda özetlenmiștir.

- Ozonlama işlemi çözgü kopma mukavemetini düşürmüș olup, ozon ile işlem süresi ve ozon oranı arttıkça da hem halat boyalı hem de slasher boyalı numunelerin çözgü kopma mukavemet değerlerinde azalma devam etmiștir. Atkı kopma mukavemet değerleri irdelendiğinde ise çözgü kopma mukavemet değerlerinde olduğu gibi ozon ile işlem süresi ve ozon oranı arttıkça her iki boyama tipi için de atkı kopma mukavemet değerleri azalmıştır. Ancak bu azalma çözgü kopma mukavemet değerleri kadar yüksek oranda gerçekleşmemiştir.

- Genel olarak ozonlama süresindeki artışın çözgü ve atkı kopma mukavemet değerlerini ozon oranına göre daha fazla etkilediği görülmüștür.

- Ozonlama işlemi uygulanmış kumaşların işlem görmemiş kumaşlara göre daha düşük sertlik değerlerine sahip olduğu, dolayısıyla ozonlamanın kumaşları yumuşattığı görülmüștür.

\section{Teșekkür}

Çalışma kapsamında denim kumaşların üretimlerinin gerçekleștirildiği BOSSA Ticaret ve Sanayi İşletmelerine ozon ile ağartma isslemlerinin gerçeklestirildiği FG Tekstil Konfeksiyon San. Tic. A.Ș.'ne teşekkürlerimizi sunarız. Çalışma Çukurova Üniversitesi Bilimsel Araştırma Projeleri (BAP) birimi tarafından FYL-2018-10748 numaralı proje kapsamında desteklenmiștir.

Not

Bu çalışmanın ön bulguları 23-25 Mayıs 2019 tarihinde Mersin'de düzenlenen 2. Uluslararası Mersin Sempozyumunda sunulmuştur.

\section{Kaynakça}

[1] Dünya Denim Kumaş Dış Ticaret Raporu, 2019. https://www.ihkib.org.tr/tr (Erişim Tarihi: 18.03.2020).

[2] Küçük, A.D., 2020, Ozonlama Proses Şartlarının Denim Kumaș Performans Özelliklerine Etkisinin İncelenmesi. Cukurova Üniversitesi, Fen Bilimleri Enstitüsü, Tekstil Mühendisliği Anabilim Dalı, Yüksek Lisans Tezi, 164s, Adana.

[3] Prabaharan, M., Nayar, R.C., Kumar, N.S., Rao, J.V. 2000. A Study on The Advanced Oxidation of a Cotton Fabric by Ozone. Coloration Technology, Cilt. 116, s. 83-86. DOI: 10.1111/j.14784408.2000.tb00024.x
- Ayrica süre parametresinin (10-20-30 dakika) ve ozon oranının (\%40-\%60-\%80$\% 100)$ kendi içlerinde sertlik değeri üzerinde anlamlı bir etkisi olmadığı tespit edilmiștir.

- 10-20 dakikalık numuneler arasındaki renk farkının 20-30 dakika işlem görmüş numuneler arasındaki renk farkından oldukça yüksek olduğu dolayısıyla ozonlama süresi arttıkça meydana gelen renk açılmasının azaldığı ve bu durumun hem halat hem slasher boyalı kumaşlar için geçerli olduğu görülmüştür.

Sonuç olarak denim yıkama sektöründe sodyum hipoklorit ve potasyum permanganat gibi konvansiyonel ağartma sistemlerine alternatif olması açısından ozonlama işleminin ağartmak/efekt vermek için çeşitli avantajlara sahip olduğu görülmüştür. Diğer ağartıcı kimyasallara göre kimyasal madde açığa çıkarmaması, çevreye zararlı olmaması, su ve enerjiden tasarruf sağlaması, yıkama tekrarlarını azaltması ve proses sürelerini kısaltması gibi birçok avantajından dolayı tercih edilebileceği görülmüștür. Bunun yanı sıra ozonlama işlemi uygulanan denim kumaşların kullanım yerine göre sahip olması gereken performans özelliklerinin de uygun değerlerde olduğu tespit edilmiştir.

[4] Micheal, M.N., El-Zaher, N.A., 2003. Efficiency of Ultraviolet/Ozone Treatments in the Improvement of the Dyeability and Light Fastness of Wool. Journal of Applied Polymer Science, Cilt. 90, s. 3668-3675. DOI: 10.1002/APP.12941

[5] Cardis, D., Tapp, C., DeBrum, M., Rice, R. G., 2007. Ozone in the Laundry Industry - Practical Experiences in the United Kingdom. Ozone:Science\&Engineering, Cilt. 29， s. 85-89. DOI: $10.1080 / 01919510601186048$

[6] Poznyak, T., Colinders, P., Chairez, I., 2007. Treatment of Textile Industrial Dyes by Simple Ozonation with Water Recirculation. J. Mex. Chem. Soc., Cilt. 51, s. 81-86

[7] Gülümser, T., Akça, C., Bahtiyari, M.İ., 2009. Yün Terbiyesinde Ozonla İşlemin Beyazlık Derecesine Etkisinin Araştırılması, Tekstil ve Konfeksiyon Dergisi, Cilt. 19, s. 52-55.

[8] Rice, R.G., DeBrum, M., Hook, J., Cardis, D., Tapp, C., 2009. Economic and Enviromental Benefits of Ozone in Ozone Laundering Systems. Ozone: Science \& Engineering: The Journal of the International Ozone Association, Cilt. 31, s. 348-356. DOI: $10.1080 / 01919510903091839$

[9] Öztürk, D., Eren, H.A., 2010. Tekstil Terbiyesinde Ozon Kullanımı. Uludağ Üniversitesi MühendislikMimarlık Fakültesi Dergisi, Cilt.15, s. 37-51.

[10] Sancar Beşen, B., 2012. Tekstil Terbiyesinde Ozon Uygulamaları İle Sürdürülebilir Ekonomik Ve İnovatif Proseslerin Geliștirilmesi. Kahramanmaraș 
DEÜ FMD 23(69), 745-754, 2021

Sütçü İmam Üniversitesi, Fen Bilimleri Enstitüsü, Tekstil Mühendisliği Anabilim Dalı, Yüksek Lisans Tezi, 155s, Kahramanmaraș.

[11] Perinçek, S., Duran, K., Korlu, A.E., 2013 Combination of Ozonation and Hydrogen Peroxide Bleaching for Linen Fabrics: Optimization of the Process Using Experimental Design Technique. Ozone: Science \& Engineering, Cilt. 35, s. 316-327.

[12] İyizaman, Ö., 2014. Dispers Boyama Atık Suyunun Ozonlama ile Geri Kazanımı ve Tekrar Kullanımı. Uludağ Üniversitesi, Fen Bilimleri Enstitüsü, Tekstil Teknolojisi Anabilim Dalı, Yüksek Lisans Tezi, 131s, Bursa.

[13] Benli, H., Bahtiyari, M.İ., 2016. Pamuklu Kumaşların Ozon-Hidrojen Peroksit Kombinasyonu ile Ağartılması ve Doğal Boyalar ile Renklendirilmesi. Tekstil ve Mühendis Dergisi, Cilt. 23, s. 189-196.

[14] Soydaş, Ş., 2016. Ozon Teknolojisinin Dokuma Havlu Kumaşlarda Hidrofilite ve Ağartma Özelliğine Etkisinin Araștırılması. Pamukkale Üniversitesi, Fen Bilimleri Enstitüsü, Tekstil Mühendisliği Anabilim Dalı, Yüksek Lisans Tezi, 129s, Denizli

[15] Kır, B., 2019. Ozon Uygulamalarının İndigo Boyalı Kumașlarda Haslık ve Tușe Üzerine Etkisinin Araştırılması. Kahramanmaraş Sütçü İmam Üniversitesi, Fen Bilimleri Enstitüsü, Tekstil Mühendisliği Anabilim Dalı, Yüksek Lisans Tezi, 83s, Kahramanmaraș.

[16] Özdemir, D., 2006. Denim Mamullerin Ağartilmasında Kullanılan Sodyumhipolklorit ve Potasyumpermanganat Yöntemlerine Alternatif Yöntemlerin Araștırılması. Ege Üniversitesi, Fen Bilimleri Enstitüsü, Tekstil Mühendisliği Anabilim Dalı, Yüksek Lisans Tezi, 130s, İzmir.

[17] TS EN ISO 13934-1, 2013. Tekstil-Kumaşların Gerilme Özellikleri-Bölüm 1:En Büyük Kuvvetin ve En Büyük Kuvvet Altında Boyca Uzamanın TayiniSerit Metodu.

[18] ASTM D4032-08. 2016. Standard Test Method for Stiffness of Fabric by the Circular Bend Procedure, ASTM International, West Conshohocken, PA.

[19] TS 2791, 2017. Tekstil-Pamuklu Blucin (Denim)Kumaş Standardı. 